\title{
Personal Reading Histories for Personal Reading Interest
}

Syofia Delfi, Jismulatif, Fangiana Safitri Diah

FKIP University of Riau

\section{ARTICLE INFO}

\section{Article history:}

Received: 11 April 2020

Revised: 13 July 2020

Accepted: 20 July 2020

Published online: 24 July 2020

Keywords:

EFL Learners

Extensive reading

Socioculture

\begin{abstract}
A B S T R A C T
Learners' reading interest is developed based on personal reading histories; meaning that they have different reading experiences. The main purpose of this article is to present the research finding about the participant's personal reading histories developing her reading interest. This is a Case Study by using document of Exploring Personal Reading Histories and interview for its instrument. The study found that the participant was introduced to reading through playing with words and numbers. After being able to read, she listened to stories indicating that stories are as the construction of words. The finding shows that the participant's reading histories develop her reading interest by recognizing reading through interesting ways, media, and guidance. These The contribution of this study is the need of the implementation of Exploring Personal Reading Histories in Extensive Reading course in order to know how learners are interested in reading as well as to remind them with their meaningful reading experiences.
\end{abstract}

\section{Introduction}

Everybody has different historical reading background indicating that reading is a personal practice. Experiences can be known if that person retells others about their meaningful reading experiences. One of the activities in Extensive Reading classroom telling about reading experiences is by practicing Exploring Personal Reading Histories as one of classroom activities suggested by Bumford and Day (2004). This activity makes the learners remind to the processes faced dealing with their reading histories. They might remember how they recognize and be able to read. They may still remember the person who introduced reading to them. They may also remember what and how she did activities dealing with reading for the first time and in the process of being able to read. They write these memories or tell it in the classroom.

Studies show how we find the learners' reading experiences found from what the learners tell in Exploring Personal Reading Histories. The implementation of

\footnotetext{
* Corresponding author.

E-mail: syofia_delfi@yahoo.com
} 
Exploring Personal Reading Histories is beneficial for learners joining Extensive Reading course as analyzed by Delfi et al. (2017). The finding shows that it begins from childhood; reading through pictures, then reading stories in the first language. In other study Delfi (2017) found that various experiences faced by learners in practicing Exploring Personal Reading Histories. It indicates that reading experiences are in individual contexts with the processes for reading competency (Delfi et al. 2018). Further study shows that learner can do reading based on their own interest, intention, and purpose with or without instruction (Delfi et al. 2019). The analysis of the research findings of the previous studies about learners' reading experiences shows that the individual context reflects on the process in becoming competence in reading (Delfi et al. 2019). Since experience is individual and the learners have different background, it is interesting to conduct a research how experiences on reading are individual for individual successful learners.

To the context of this study, the result of analysis about English Study Program learners of FKIP University of Riau shows that learners' reading performance needs to be improved. The result shows that the learners' reading competence based on Reading courses is in the range 66-80 (B) and Reading competence based on TOEFL test on Reading section are in the range 51\% - $80 \%$ (Delfi and Yamat, 2017). It means that the performance of reading competence was the performance after they took intensive reading courses (Reading I, Reading II, and Reading III). Meanwhile, the performance of TOEFL score is the performance after taking the whole reading courses including Extensive Reading course. Especially, the learners got TOEFL score after one year finishing learning Extensive Reading. It is supposed that they recognized the concept of extensive reading and practicing extensive reading. Especially the objective of extensive reading "to construct the learners' reading habit and joyful reading" as what Bumford and Day $(1998,2004)$ means in which extensive reading is an approach to language teaching as $\mathrm{t}$

The following discussion is about theories related to this study.

\section{Characteristics of Extensive Reading}

Day and Bamford $(1998,2004)$ classify extensive reading into10 characteristics. The characteristics are: i) reading as much as possible (in and definitely out of the classroom), ii) various reading materials encouraging reading for different reasons and in different ways, iii) students' freedom in selecting and stopping reading, iv) reading purposes on pleasure, information, and general understanding determining on the material and the students' interest, v) the reading activity as its own reward, vi) Reading materials within the students' linguistic competence, vii) individual pace on reading, viii) faster Reading speed, ix) teachers' orientation for the goals of the program, and x) Teachers as a role model. These characteristics shows that the one playing roles in practicing extensive reading as a course is students guiding by teachers/ lecturers through orientations and models. It means that teachers/ lecturers should not expect the students to do extensive reading if they do not know why and how they do it. 
These characteristics also indicate how extensive reading is different from intensive reading. The difference is not only in terms of the meaning but also in terms of conducting the course of Extensive Reading. Bumford and Day (2004) claim that the readers practicing extensive reading read a lot of reading materials for information and enjoyment. They choose their own reading materials. ER focuses on reading as much as possible to instill enjoyment in reading as well as to learn new information while reading (Brown, 2001 and Anderson and Nunan, 2008). The characteristics are commonly used as a reference used by researchers and writers of books and articles.

The background knowledge before reading a text prepares readers to do reading in the future. Jung et al. (2020) found that the learners' reading experiences beginning from childhood reflect on their motivation. The motivation reflects on the learners' reading attitude. Istiqomah et al. (2020) claim that the learners' attitude is needed to be known. The positive attitude affects on the learners' learning interest (Erwiza et al. 2019). It shows that the positive attitude on reading develops the learners' reading interest. Yarnefi et al. (2019) claim that interest refers to the feeling of happy may attract the learners' interest to pay attention on activities. It also means that the students' interest in reading reflects on the sense of happiness to do reading. The finding of Parkaew \& Fongpaiboon (2018) suggest that the use of Extensive Reading Approach is to increase the students' positive attitudes towards reading. Rong et al.(2019) discuss the use of extensive reading for EFL/ESL learners. The use is in terms of increasing competence in language components and language skills as well as the attitude in reading. Therefore, it is beneficial to conduct on study on extensive reading area, especially the learners' historical background developing their reading interest.

\section{Exploring Reading Personal Reading Histories as ER Practices}

The teacher/ the lecturer is expected to vary classroom activities in practicing extensive reading, especially reading is not mainly as classroom activity. The variations might be chosen by considering the meetings: at the beginning, middle, or end of the semester. It is also possible based on the reading materials that they read outside of the classroom. It depends on the teacher/ the lecturer to consider the appropriate activities. One of the appropriate activities attracting the students' reading interest is Exploring Personal Reading Histories. It is in line with the objective of extensive reading course if it is implemented. It is done at the beginning of the semester in which providing the learners telling their reading experiences. The learners may tell why and how they do reading and who involve in the process of becoming competence in reading. They may also tell the role of reading for them.

In order to match the activity and the goals of implementing extensive reading, it is needed to consider levels, aims, preparation, and procedures, and questions before conducting the activity (Bumford and Day (2004). The teacher/ lecturer select the appropriate activity for appropriate levels (beginner, intermediate, or advance). They also need to set the aims in order to obtain the focus of the learning process. Preparation means to have someone as a role model in order to 
tell their experiences. Then, the teacher/ lecturer needs to organize the procedure as well as constructing questions. The questions are dealing with the learners' reading background. It shows that applying Exploring Personal Reading Histories is really like organizing teaching and learning process in which focuses on the class to be taught.

Bumford and Day (2004) make a list of questions to be asked in Exploring Personal Reading Histories Exploring Personal Reading Histories

- What are your first memories of reading?

- Did anyone read to you? If so, who? If not, why was that?

- What ideas of things did you enjoy reading most?

- Do you still enjoy reading these kinds of things today? If not, how has your reading changed?

- Which author or types of reading have been most important to you?

- What role does reading play in your life now (for example, as a parent or for work, pleasure, community, or religious purposes?

The components of these questions are as a reference in designing questions implemented Exploring Personal Reading Histories in Extensive Reading course in this study. In practicing Exploring Personal Reading Histories , context is needed to consider be considered in learning activity in order to perceive the focus of the activity as suggested by (Kamaruddin and Ahmal 2018). They state that involving in the context of the topic learnt is appropriate in perceiving the materials learnt

The previous studies on Exploring Personal Reading Histories in Extensive Reading course of the English Department students of FKIP University of Riau show how learners experienced reading. It was as reading experiences in childhood: reading through pictures and by reading stories in the first language. They experienced valuable reading experiences in reading English texts: reading a lot of reading materials, sharing others, and reading for entertainment and knowledge (Delfi, 2017). Experiences developed process indicating the meaningful role of parents and teachers in the process of reading (Delfi et al., 2018). Furthermore, Delfi et al. (2019) found that the learners who are interested in reading will do reading without instruction. Delfi et al. (2019) conclude that the learners' interest in reading is based on constructive process for valuable experiences.

\section{Learning Theory}

The suitable learning theory for this study is Sociocultural theory recognizing Vygotsky' theory. Social interaction in this theory plays the fundamental role for developing cognition. The perspectives Vygotsky's theory on the second language learning are in terms of mediation, self - regulation, scaffolding, zone of proximal development, micro genesis, private and inner speech, and activity theory (Lightbown and Spada 2011). It shows that a learner is as individual interacting with others. In the process of learning, a learner is an individual who is with 
his/her learning background before interacting in learning context. Kao (2010) believes that language learning is as a social practice involving learners. They are supposed as active participants in constructing learning process.

Sociocultural theory is appropriate to be implemented in developing the learners' reading comprehension. From sociocultural perspectives, it is believed that learners are socially situated to interact in the process of literacy learning (Davidson, 2010). Panhwar et al. (2016) found that it affects on how the learners develop individually: developing students' center and autonomous learning. The learners will be enable to argue, discuss and be critical and create their own knowledge as the context facilitates them. Interaction might happen by using technology in the process of learning. It directs the learners to build and share knowledge (Shih 2017). If the learners keep on practicing learning individually, it will develop self-regulation on the learners in order to have a successful future oriented attitude (Junita et al. 2018).

The use of interaction can be seen in the process of learning reading and writing. Literacy learning contributes knowledge to learning achievement. It is expected that learners can gain it through the process of interaction from those support their learning as scaffolding in sociocultural theory. Studies show how scaffolding in learning process is (Reza and Mahmud 2013; Shabani, 2016). Reza and Mahmud (2013) found the improvement on reading comprehension for EFL learners in an EFL context. It shows that learners learn conducive and facilitative context for interaction between learners with teachers as well as with peers. The interaction is in terms of scaffolding. Teachers mean professional that development are in terms of cognitive, affective, social and contextual (Shabani, 2016).

The learners' interaction based sociocultural perspectives is also supported by the involvement of their parents (Zhang, 2015). Parents engage with their children in talking about school and checking homework. The schools emphasize on academic success, meanwhile, the teachers' treatment includes the social environment in learning activities. This means that people around learners like teachers, peer group, and parents facilitate the learners developing their learning. Bergbauer and Staden (2018) found the effect of parents who engage with their children' learning activities is in talking about school and checking homework, the school's emphasis on academic success as well as the teachers' treatment in involving the social environment in learning activities. Ayu et al. (2020) believe that family environment also has roles for learners' achievement.

The phenomena of English Study Program learners of FKIP University of Riau about their reading performance and the use of practicing Exploring Personal Reading Histories, it is expected to study about learners' reading experiences constructing their reading interest. Therefore, this study will answer questions: (1) What are the learner reading experiences? and (2) How do the reading experiences develop the learners' reading interest? 


\section{Methodology}

This study is about personal reading experience and the appropriate study is a Case Study. It is about a case of an English Department Students of FKIP Riau University. The case is in terms of her reading experiences. The experiences are based on what the participant mentioned in practicing Exploration Personal Reading Histories in Extensive Reading Course. The appropriate research design is a Case Study since the phenomenon meets the research question as Yazan (2015) means.

The participant of this study was chosen purposively. She is a semester fourth students of English Study Program, the Faculty of Teacher Training and Education, University of Riau. The participant was chosen since she met to the criteria considered in this study. Criteria for choosing this participant deal with time taking Extensive Reading course, competence in Extensive Reading course and exploring their reading experiences in written and oral. The learner who met these criteria was only one person, namely Sarah (pseudo name). She was considered because she got the highest score in Extensive Course and she was the only person who explored personal reading histories appropriately. Besides, it is also the first time for her taking Extensive Reading course.

In order to answer the research question of this study, the instrument used was the document of the learner' Exploration of Personal Reading Histories and one timeinterview. These instruments are included as two types of instruments suggested by Creswell (2014). The use of interview is to get the deep information about the participants' reading experiences. It was conducted after the document was analyzed. The document and the interview were analyzed by classifying into themes (open coding) to be categories. In the process of analysis, the documents and the description of the verbatim transcription of interview were read and reread to code participant's responses and classifications into themes and categories. Table 1 is an example of the process of analysis in order to gain the themes of the data.

Table 1: The Analysis for Themes (Open Coding) for Exploring Reading Histories of English Department Students of University of Riau

\begin{tabular}{ccc}
\hline Question & Response & Theme \\
\hline Did anyone read to you? & - My mother often read for & facilitator \\
If so, who? If not, why & me and my brother in order & beneficial activity \\
was that? & to make us be familiar & \\
\hline
\end{tabular}

\section{Results and Discussion}

The result of this study is as the result of data analyses. The analyses were based on the data gained from document of Exploring Personal Reading Experiences and interview. They were analyzed in order to find out Sarah's (pseudo name) 
reading experiences. The classification of themes is in order to answer the research question.

\section{Learners' Reading Experiences}

The result of the analysis of themes (Open Coding) for Exploring Personal Reading Histories of learners of the Faculty of Teacher Training and Education University of Riau is as follows.

\section{Sarah's Reading Experiences}

- Recognizing letters and numbers before entering kindergarten

- learning through playing words and numbers before entering kindergarten

- Listening to children' stories

- Visiting library

- Being able to read before entering kindergarten

- Recognizing all kinds of reading materials

Sarah's reading experiences might be different or the same as the other's reading experiences. As an individual student, Sarah experienced based on her personal historical background which are not exactly the same or different from the other students. Sarah's reading experiences began through the enjoyable media. Her parents provided her with the toys relating with reading as well as guidance to do reading activities. Sarah said "The most unforgettable memory that I have gotten was ... My mother bought me some toys like letters and numbers" (document). Her parents, especially her mother, did not only facilitate her with media but also guided her recognizing letters and numbers. Sarah said "She taught me how to pronounce the letters and numbers and how to read" (document). Her mother was as a facilitator in guiding her. She taught and let Sarah to do it by herself. She would guide Sarah if Sarah made mistake. Sarah said "She taught me how to read. Then, asked me to do it by myself and corrected if I made mistakes" (document).

Another experience developing Sarah's interest towards reading was visiting library and bookstore when she was a child. Sarah said "She also often took me to book store and library" (interview). The preceding experiences developed Sarah's interest towards reading by recognizing any reading materials; books and stories. Her intention at that time was to know the content of books. This experience develops her reading interest in childhood. It shows that reading interest is developed through enjoyable process. These experiences made her able to read before entering kindergarten. She also recognizes her own reading competence in which she could evaluate her ability which is more than the other peer groups. Reading any reading materials develops her interest to read the other reading materials.

Reading experiences that Sarah faced in childhood was enjoyable. Sarah said "She put wall paper letters and numbers in my room, so I can read every day" (document). It makes Sarah have chances to pay attention on the words. It shows 
that Sarah faced valuable experiences developing her reading interest; recognizing letters, numbers and words, guidance in playing dealing words, read stories before reading. These experiences made Sarah enjoy reading. She said "...since then, I love reading very in kindergarten rather than others" (document).

\section{Discussion}

Meaningful experiences that Sarah faced show how she faced meaningful reading experiences. The experiences develop her reading experiences. These experiences direct her to be a successful learner in Extensive Reading course.

Sarah was in the context in which she was provided with the facilities directing her to do reading activities. She was facilitated with books and interesting toys attracting interest to reading. Besides, she was also guided to do reading, to go to library and bookstore before school age. Sarah's experiences show the role of contexts supporting and guiding learner's better reading development as Davidson (2010) means. This is reflection of socio-cultural theory which is potential for creating language pedagogy based on context and adapted in different context (Panhwar et al., 2016), especially involving the role of parents (Zang, 2015 \& Bergbauer and Staden, 2018).

The facilities and treatment provided before recognizing attract Sarah's interest to the activity of reading. It shows that Sarah supposes that reading is an interesting activity. It also means she could understand story by reading. The finding indicates the meaning of the earlier reading experience. It shows that experiences as background knowledge makes readers do reading in the future. To Sarah's context, introduced reading at the first time constructs her positive attitudes toward reading. It supports Erwiza's et al. (2019) about the positive attitude affecting on the learners' learning interest. It indicates that Sarah expresses the feeling of happiness attracting her interest to pay attention on activities as Yarnefi et al. (2019) means. Sarah's earlier reading experience is in line with Jung et al. (2020) who found that the learners' reading experiences beginning from childhood. This experience reflects on Sarah's motivation. The motivation reflects on her reading attitude.

The result of this study shows the meaningful role of the one who introduced reading for the first time to Sarah. The experiences are based the context of the role of people around her, especially her mother in attracting and developing her reading interest. It makes Sarah interest to do reading based on her own interest. Reading experiences faced by Sarah is experiences begun from enjoyable experiences developing her reading interest. She also was also facilitated with the interesting and appropriate instrument and guided with interesting and appropriate ways. The experiences make her be a successful learner in Extensive Reading course.

The finding shows answer of the research questions. The answers of the first question "What are the learner reading experiences?" The study found that the participant was introduced to reading through playing with words and numbers. 
After being able to read, she listened to stories indicating that stories are as the construction of words. How do the reading experiences develop the learners' reading interest? The finding shows that the participant's reading histories develop her reading interest by being introduced reading through interesting ways, media, and guidance.

The contribution of this study is the need of the implementation of Exploring Personal Reading Histories in Extensive Reading course. Studies show the role of the course; in the process of learning in general, learning English, and specifically in developing reading competence (Parkaew \& Fongpaiboon; 2018) and in increasing the students' positive attitudes towards reading (Rong et al. 2019). The learners' attitude is needed to be known (Istiqomah et al. 2020).

\section{Conclusion}

The research questions to be answered in this Case Study is (1) What are the learner reading experiences? and (2) How do the reading experiences develop the learners' reading interest? One student met the characteristics of this case choosen purposively. The result of comparative analysis which classified into themes and categories show that the participants experienced reading meaningfully through enjoyable ways and facilities. Therefore, these make the learners' interest be developed. The finding shows that learners' reading interest should be considered at the beginning when they are introduced to "reading". To the context of of this study in which the participant is a student taking Extensive Reading class. In joining this class, the students are expected to enjoy reading. This study shows that enjoyed reading or interested to do reading is not something asked but something done through interesting ways, media, and guidance. This is as the implication of this study: for teaching and learning Extensive Reading.

\section{References}

Anderson, J. N, \& Nunan, D. (2008). Practical English Language; Reading (1ed.). New York. McGraw-Hill ESL/ELT.

Ayu, S., Makhdalena, \& Sumarno. (2020). Effect of Family Environment and Education Costs on Students' Achievement with Interest in Reading as Intervening Variable. Journal of Educational Sciences, 4 (1), 164-175

Benard, R.H. \& Ryan, W.G. (2010). Analyzing Qualitative Data; Systematic Approach 1ed.). California. SAGE Publication, Inc.

Bergbauer, A., \& Staden, S. V. (2018). Social interaction determinants of south African reading literacy achievement: Evidence from prePIRLS 2011. International Journal of Instruction. 11 (2), 1308-1470.

Bumford, J., \& Day, R. R. (1998). Extensive reading activities in the second language classroom ( $1^{\text {st }}$ ed.). UK. Cambridge University Press.

Bumford, J., \& Day, R. R. (2004). Extensive reading activities for teaching language (1ed.). UK. Cambridge University Press. 
Brown, H. D. (2001). Teaching by Principles an Interactive Approach to Language /Pedagogy (3rd ed.), New York. Pearson Education Inc.

Creswell, W. J. (2014). Research Design. United States of America, SAGE.

Davidson, K. (2010). The integration of cognitive and sociocultural theories of literacy development: Why? How?.The Alberta Journal of Educational Research. 56( 3), 246-256.

Delfi, S., \&Yamat, H. (2017). Extensive reading in developing language Competency for Indonesian EFL Learners Majoring in English. IJELTAL, 2(1), 153-164.

Delfi, S., \&Yamat, H. (2017). An Analysis of reading performances of Indonesian EFL Learners for Extensive reading practice. Journal of Educational Sciences, 1(1), 35-44

Delfi, S., (2017). Reading experiences on the personal exploration of reading histories of students of FKIP Universtas Riau. Atlantis Press, ASSEHR. 10, 173-178

Delfi, S., Diah. S. F. \& Jismulatif. (2017). An Analysis of Exploring Personal Reading Histories for Learners of FKIP University of Riau, Proceedings ICES, 363-369.

Delfi, S., Diah. S. F. \& Jismulatif. (2018). Exploring personal reading histories in developing reading interest of English Study Program learners of University of Riau. IJELTAL, 2(2), 35-44

Delfi, S., Diah. S. F,.\& Maria S. (2018). Sociocultural Perspectives in Exploring Personal Reading Histories for Learners of English Study Program learners of University of Riau. Proceeding $-2^{\text {nd }}$ UR-ICES, 353-361

Delfi, S., Diah. S. F,.\& Maria S. (2019). Reading Experiences on Exploring personal reading histories in developing reading of English Study Program learners of University of Riau. JES, 3(3), 303-317

Delfi, S., Diah. S. F. \& Jismulatif. (2019). An Analysis of Learners' Reading Experiences Developing Reading Interest Proceedings - SS9 \&UR-ICES, 701-709

Erwiza, Kartikowati, S., Gimin, (2019) Factors Affecting the Concentration of Learning and

Social Thinking on Students' Learning Achievement in Economic Subject. Journal of Educational Sciences, 3(2), 205-215

Istiqomah, Suwondo, \& Firdaus, L. N (2020). Environmental Education in Formal Attitudes of Environmental Care for Students. Journal of Educational Sciences, 4(1), 164-175

Junita, D., Suarman, S., \& Kartikowati, S. (2018). Accomplishment motivation and soft skill related to learning achievement. Journal of Educational Sciences, 2(2), 83-89

Jung, S., Choi, N., \& Jung, S. (2020) The Effect of the First Reading Experience on Reading and Academic Achievement of Elementary First Graders. Ilkogretim online 19(2) 415-425 / ilkogretim online. org.tr

Kamaruddin, K., \& Ahmal, A. (2018). The study of history based on local antiquity: A case study of existence of Kampar River in Analyzing the past Maritime in teaching history. Journal of Educational Sciences, 2(1), 72 82 
Kao, P. (2010). Examining Second Language Learning Taking a Sociocultural Stance. RECLS 7, 113-131

Lightbown, P. M., \& Spada, N. (2013). How Languages are Learned 4th edition-Oxford Handbooks for Language Teachers. Oxford University Pres McLeod, S. (2007). Lev V Vygotsky.

Nwabudike, C. E., \& Anaso, G. (2013). The Effects of Extensive Reading on Some

ESLLearners' Vocabulary Development: A Case Study of NigerianTurkishInternational Colleges, Kano. International Journal of Humanities and Social Science Invention, 24), 34-42.

Nor, M. N., \& Rashid, A., R. (2018). A review of theoretical perspectives on language learning acquisition. Kasetsart Journal of Social Sciences. 39, 161-167.

Parkaew, K. \& Fongpaiboon, A., (2018). Effects of Extensive Reading on Thai Tertiary St. students' Reading Attitudes, Arab World English Journal 9 (1), 207-219

Reza, Ghafar S. \& Mahmood, Dehqan. (2013). Sociocultural Theory and Reading Comprehension: The Scaffolding of Readers in an EFL Context. International Journal of Research Studies in Language Learning 2 (3), 6780.

Rong, Ng, Q, Renandya, A., W. \& Chong, C., Y., M. ( 2019) Extensive Reading: Theory, Research, and Implementation. TEFLIN 30(2), 171-186

Shabani, K. (2016). Applications of Vygotsky's sociocultural approach for teachers' Professional development. Cogent Education, 3, 1-10Salem, A. A. M. S. (2017). Scaffolding Reading Comprehension Skills. English Language Teaching, 10(1), 1916-4750.

Shih, P., Velan, G. R. \& Shulruf. B. (2017). Shared values and socio-cultural norms: E-learning technologies from a social practice perspective. Issues in Educational Research. 27 (3), 550-556.

Porkaew, K. \& Fongpaiboo, A. (2018). Effects of Extensive Reading on Thai Tertiary Students' Reading Attitudes University Students. Arab World English Journal, 9 (1) 207-219.

Yarnefi, Y., Kartikowati, S., \& Gimin, G. (2019) Interest and Factors Affecting Students in Choosing Social Department, Journal of Educational Sciences, 3(2), 227-236

Yazan. B. (2015). Three Approaches to Case Study in Education: Yin, Merriam, and Stake. The Qualitative Report, 20(2), 134-152.

Zhang, Q. (2015). Emergent Literacy as Sociocultural Practice: How Well Do New Zealand Parents Fit with Ta Whariki?.Journal of Childhood Literacy, $17(1), 1-23$.

How to cite this article:

Delfi, S., Jismulatif, \& Diah, S. F. (2020). Personal Reading Histories for Personal Reading Interest. Journal of Educational Sciences, 4(3), 694-704. 